ART. LIII.-On the Source of Afuscular Power; by EDWARD FrankLaND, Ph.D. F.R.S.'

What is the source of muscular power? Twenty years ago, if this question had been asked, there were but few philosophers who would have hesitated to reply, "The source of muscular power is that peculiar force which is developed by living animals, and which we term the vilal force /" but the progress of scientific discovery has rendered the view implied in such an answer so utterly untenable that, at the present moment, no one possessing any knowledge of physical science would venture to return such a reply. We now know that an animal, however high its organization may be, can no more generale an amount of force capable of moving a grain of sand, than a stone can fall upwards or a locomotive drive a train without fuel. All that such an animal can do is to liberate that store of force, or potential energy, which is locked up in its food. It is the chem. ical change which food suffers in the body of an animal that lib. erates the previously pentrup forces of that food, which now make their appearance in the form of actual energy -as heat and mechavical motion.

From food, and food alone, comes the maller of which the animal body is built up; and from food alone come all the different kinds of physical force which an animal is capable of man. ifesting.

The two chief forms of force thus manifested are Heat and Muscular motion or mechanical work, and these have been almost universally traced to two distinct sources-the heat to the oxyd-

- Mr. Baxendell sends us the following table of magnitudes:

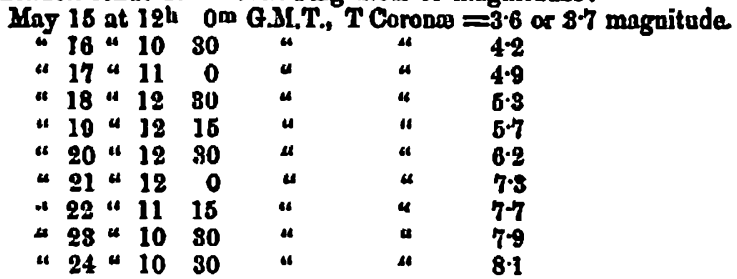

I From the Proc. Roy. Inst. of Great Britain, June 8, 1886. 
ation of the food, and the mechanical work to the oxydation of the muscles.

This doctrine, first promulgated, the speaker belioved, by Liebig, occupies a prominent position in that plilosopher's justly celebrated 'Chemico.Physiological Essays.'

In his work entitled 'Die organische Chemie in ibrer Anwendung auf Physiologie und Pathologie, Braunschweig, 1842,' Liebig says, "All experience teaches that there is only one source of mechanical power in the organism, and this source is the transformation of the living parts of the body into lifeless compounds.... This transformation occurs in consequence of the combination of oxygen with the substance of the living parts of the body." And again, in his 'Letters on Chemistry, 1851,' p. 366, referring to these living parts of the body, he says, "All these organized tissues, all the parts which in any way manifest force in the body are derived from the albumen of the blood; all the albumen of the blood is derived from the plastic or sanguineous constituents of the food, whether animal or vegetable. It is clear, therefore, that the plastic constituents of food, the ultimate source of which is the vegetable kingdom, are the conditions essential to all production or manifestation of force, to all these effects which the animal organism produces by means of its organs of sense, thought, and motion." And again, at page 374, he 8ays, "The sulphurized and nitrogenous constituents of food determine the continuance of the manifestations of force; the non-nitrogenous serve to produce heat. The former are the builders of organs and organized structures, and the producers of force; the latter support the respiratory process, they are malerials for respiration."

This doctrine bas since been treated as an almost selfevident truth in most physiological text-books; it has been quite recently supported by Ranke ; and, in his lecture 'On the Food of Man in relation to his Useful Work, 1865,' Playfair says, page 37, "From the considerations which have precelled, we consider Liebig amply justified in viewing the non-nitrogenous portions of food as mere heat-givers. . . . While we have been led to the conclusion that the transformation of the tissues is the source of dynamical power in the animal." At page 30 he also says, "I agree with Draper and others in considering the contraction of a muscle due to a disintegration of its particles, and its relaxation to their restoration. ... All these facts prove that transformation of the muscle through the agency of oxygen is the condition of muscular action." Finally, in a masterly review of the present relations of chemistry to animal life, published in March last," Odling says, page 98, "Seeing, then, that

2 'Tetanus eine Physiologische Btudie.' Leipsig, 1865.

- 'Iectures on Animal Chemistry.' 
muscular exertion is really dependent upon muscular oxydation, we have to consider what should be the products, and what the value of this oxydation." . . A And again, page 103, "The slow oxydation of so much carbon and hydrogen in the humnn body, therefore, will always produce its due amount of heat, or an equivalent in some other form of energy; for while the latent force liberated by the combustion of the carbon and hydrogen of fat is expressed solely in the form of heat, the combustion of an equal quantity of the carbon and hydrogen of voluntary muscle is expressed chiefly in the form of motion."

Nevertheless, this view of the origin of muscular power has not escaped challenge. Immediately after its first promulgation, Dr. J. R. Mayer wrote," "A muscle is only an apparatus by means of which the transformation of force is effected, but it is not the material by the chemical change of which mechanical work is produced." He showed that the $15 \mathrm{lbs}$. of dry muscles of a man weighing $150 \mathrm{lbs}$. would, if their mechanical work were due to their chemical change, be completely oxydized in eighty days, the heart itself in eight days, and the ventricles of the heart in two and a half days. After endeavoring to prove by physiological arguments that not one per cent of the oxygen ab. sorbed in the lungs could possibly come into contact with the substance of the muscles, Mayer says, "The fire-place in which this combustion goes on is the interior of the blood vessels, the blood bowever-a slowly-burning liquid-is the oil in the flame of life. . . . Just as a plant-leaf transforms a given mechanical effect, light into another force, chemical difference, so does the muscle produce mechanical work at the cost of the chemical difference consumed in its capillaries. Heat can neither replace the sun's rays for the plant, nor the chemical process in the animal: every act of motion in an animal is attended by the consumption of oxygen and the production of carbonic acid and water; every muscle to which atmospheric oxygen does not gain access ceases to perform its functions."

But Mayer was not the first to conceive this view of muscular action. Nearly 200 years ago, a Bath physician, Dr. John Mayow, ${ }^{\circ}$ distinctly stated that for the production of muscular motion two things are necessary - the conveyance of combustible substances to the muscle by the blood, and the access of oxygen by respirntion. He concluded that the chief combustible substance so used was fut. A century before Priestley isolated oxygen, Mayow was aware of its existence in the air, in nitre, and in nitric acid; he knew that combustion is supported by the oxygen of the air, and that this gas is absorbed in the

' 'Die organische Bewegung in ilırem Zueammenhange mit dem Stoffwechsel,' 1845.

- 'De Motu musculari,' 1681. Mayow was born In 1645, and died 1679. 
lungs by the blood, and is absolutely necessary for muscular activity.

For two decades this doctrine sank into oblivion; and it is only within the last two years that it has been again advanced, chiefly by Haidenhain, "Traube, and, to a limited extent, by Donders.'

Experimental evidence was, however, still wanting to give permanent vitality to the resuscitated doctrine; for although the laborious and remarkable investigations of $\mathrm{Voit}^{\mathrm{s}}$ and of Edward Smith point unmistakably in the direction of Mayow and Mayer's hypothesis, yet the results of these physiologists were not sufficiently conclusive to render the opposite view untenable. This want of data of a sufficiently conclusive character has been supplied by a happily conceived experiment undertaken by Fick and Wislicenus in the autumn of last year, and described in the 'Philosophical Magazine,' vol. xxxi, p. 485. In the application of these data, however, to the problem now under consideration, one important link was found to be wanting, viz., the amount of actual energy generated by the oxydation of a given weight of muscle in the human body. Fick and Wislicenus refer to this missing link in the following words: "The question now arises what quantity of heat is generated when muscle is burnt to the products in which its constituent elements leave the human body through the lings and kidneys? At present, unfortunately, there are not the experimental data required to give an accurate answer to this important question, for neither the heat of combustion of muscle nor of the nitrogenous residue (urea) of muscle is known." Owing to the want of these data, the numerical results of the experiments of Fick and Wislicenus are rendered less conclusive against the hypothesis of nuscle combustion than they otherwise would have been, while similar determinations, which have been made by Edward Smith, Haughton, Playfair, and others, are even liable to a total misinterpretntion from the same cause.

The speaker stated that he had supplied this want by the calorimetrical determination of the actaul energy evolved by the combustion of muscle and of urea in oxygen. Availing himself of these data he then proceeded to the consideration of the problem to be solved, the present condition of which might be thus summed up:-It is agreed on all hands that muscular

- Mechanische Leistung Warmeentwiekelung und Stofiumsatz bol der Muskelthatigkeit, 1864.

Is this is passing through the press, the spenker has bucome aware that Messra. Lawes and Gilbert adrocated this doctrine in 1862, and repeatedly since; their opinions boing founded upon experiments on the feeding of cattle.

- Unterauchungen über den Einfluss des Kochsalzes, des Kaffecs und der Muskelberregungen auf den 8toffwechsel,' p. 160. Munich, 1860.

- Phil. Trans, 1861, p. 747. 
potrer is derived exclusively from the mutual chemical action of the food and atmospheric oxygen; but opinions differ as to whether that food must first be converted into the actual organized substance of the muscle, before its oxydation can give rise to mechanical force, or whether it is not also possible that muse cular work may be derived from the oxydation of the food, which has only arrived at the condition of blood and not of organized muscular tissue.

The importance of this problem can scarcely be overrated; it is a corner-stone of the physiological edifice, and the key to the phenomena of the nutrition of animals. For its satisfactory 80lution the following data require to be determined:

1st. The amount of force or actual energy generated by the oxydation of a given amount of muscle in the body.

$2 \mathrm{~d}$. The amount of mechanical force exerted by the muscles of the body during a given time.

$3 d$. The quantity of muscle oxydized in the body during the same time.

If the total amount of force involved in muscular action, as measured by the mechanical work performed, be greater than that which could possibly be generated by the quantity of muscle oxydized during the same time, it necessarily follows that the power of the muscles is not derived exclusively from the oxydation of their own substance.

As regards the first datum to be determined, it is necessary to agree upon some unit for the measurement of mechanical force. The unit most commonly adopted is that represented by the lifting of a kilogram weight to the beight of one meter. The researches of Joule and Mayer have connected this standard unit with heat;-they prove that the force required to elevate this weight 425 times will, when converted into heat, raise the temperature of an equal weight of water $1^{\circ} \mathrm{C}$. If this weight were let fall from a height of $\mathbf{4 2 5}$ meters, its collision with the earth would produce an amount of heat sufficient to raise the temperature of 1 kilogram of water $1^{\circ} \mathrm{C}$. The same heating effect would also of course be produced by the full of 425 kilo. grams through 1 meter. This standard of force is termed a melerkilogram; 10 and 425 meterkilograms are equal to that amount of heat which is necessary to raise the temperature of 1 kilogram of water through $1^{\circ} \mathrm{C}$. If then it be found that the heat evolved by the combustion of a certain weight of charcoal or muscle, for instance, raises the temperature of 1 kilogram of water tbrough $1^{\circ} \mathrm{C}$., this means, when translated into mechanical power, 425 meterkilograms. Again, if a man weighing 64 kilograms climbs to a height of 1,000 meters, the ascent of his

${ }^{30}$ I follor the example of the Registrar-Goneral in abbreviating the French word gramme to gram.

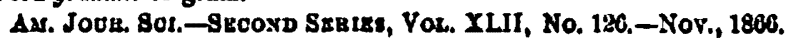


body to this height represents 64,000 meterkilograms of work; that is, the labor necessary to raise a kilogram weight to the height of 1 meter 64,000 times.

In order to estimate the amount of actual energy generated by the oxydation of a given amount of muscle in the body, it is necessary to determine, first, the amount of actual energy generated by the combustion of that amount of muscle in oxygen, and then to deduct from the number thus obtained the amount of energy still remaining in the products of the oxydation of this quantity of muscle which leave the body. Of these products, urea and uric and hippuric acids are the only ones in appreciable quantity which still retain potential energy on lenving the body, and of these the two latter are excreted in such small proportions that they may be considered as urea without introducing any material error into the results.

These determinations were made in Lowis Thompson's calorimeter, which consists of a copper tube to contain a mixture of chlorate of potash with the combustible substance, and which can be enclosed in a kind of diving.bell, also of copper, and so lowered to the bottom of a suitable vessel containing a known quantity (2 liters) of water. The determinations were made with this instrument in the following manner:-19.5 grams of chlorate of potash, to which about one-eighth of peroxyd of manganese was added, was intimately mixed with a known weight (generally about 2 grams) of the substance whose potential energy was to be determined, and the mixture being then placed in the copper tube above mentioned, a small piece of cotton thread, previously steeped in chlorate of potash and dried, was inserted in the mixture. The temperature of the water in the calorimeter was now ascertained by a delicate thermometer; and the end of the cotton thread being ignited, the tube with its contents was placed in the copper bell and lowered to the bottom of the water. As soon as the combustion reached the mixture a stream of gases issued from numerous small openings at the lower edge of the bell and rose to the surface of the water-a height of about 10 inches.

At the termination of the deflagration, the water was allowed free access to the interior of the bell, by opening a stop-cock connected with the bell by a small tube rising above the surface of the water in the calorimeter. The gases in the interior of the bell were thus displaced by the incumbent column of water, and by moving the bell up and down repeatedly, a perfect equilibrium of temperature throughout the entire mass of water was quickly established. The temperature of the water was again carefully observed, and the difference between this and the previous observation determines the calorific power or potential energy, expressed as heat, of the substance consumed. 
The value thus obtained is, however, obviously subject to the following corrections:-

1. The amount of heat absorbed by the calorimeter and appatus employed, to be added.

2. The amount of heat carried away by the escaping gases, after issuing from the water, to be added.

3. The amount of heat due to the decomposition of the chlorate of potash employed, to be deducted.

4. The amount of heat equivalent to the work performed by the gases generated in overcoming the pressure of the atmosphere, 10 be udded.

Although the errors due to these causes to some extent neutralize each other, there is still an outstanding balance of sufficient importance to require that the necessary correctious should be carefully attended to.

The amount of error from the first cause was once for all ex. perimentally determined, and was added to the increase of temperature observed in each experiment.

The amount of heat carried away by the escaping gases after issuing from the water may be divided into two items, viz.:-

a. The amount of heat rendered latent by the water which is carried off by the gases in the form of vapor.

b. The amount of heat carried off by these gases by reason of their temperature being above that of the water from which they issue.

It was ascertained that a stream of dry air when passed through the water of the calorimeter, at about the same rate and for the same period of time as the gnseous products of combustion, depressed the temperature of the water by only $0^{\circ} .02 \mathrm{C}$.

By placing a delicate thermometer in the escaping gases, and another in the water, no appreciable difference of temperature could be observed. Both these items may therefore be safely neglected.

The two remaining corrections can be best considered together, since a single careful determination eliminates both. When a combustible substance is burnt in gaseous oxygen, the conditions are essentially different from those which obtain when the same substance is consumed at the expense of the combined or solid oxygen of chlorate of potash. In the first case the products of combustion, when cooled to the temperature of the water in the calorimeter, occupy less space than the substances concerned in the combustion, and no part of the energy developed is therefore expended in external work, that is, in overcoming the pres. sure of the atmosphere. In the second case, both the combustible and the supporter of combustion are in the solid condition, whilst a considerable proportion of the products of combustion are gases. The generation of the latter cannot take place without the performance of external work, for every cubio inch pro- 
duced must obviously, in overcoming atmospheric pressure, perform an amount of work equivalent, in round numbers to the lifting of a weight of $15 \mathrm{lbs}$. to the height of one inch. In performing this work the gases are cooled, and consequently less beat is communicated to the water of the calorimeter. Nevertheless, the loss of beat due to this cause is but small. Under the actual conditions of the experiments detailed below, its amount would only have increased the temperature of the water in the calorimeter by $0^{\circ} .07 \mathrm{C}$. Even this slight error is entirely elim. inated by the final correction which we have now to consider.

It is well known that the decomposition of chlorate of potash into chlorid of potassium and free oxygen is attended with the evolution of heat. If a few grains of peroxyd of manganese, or better, of peroxyd of iron, be dropped into an ounce or two of fused chlorate of potash which is slowly disengaging oxygen, the evolution of gas immediately proceeds with great violence, and the mixture becomes visibly red hot, although the external application of heat be discontinued from the moment when the metallic peroxyd is added. The latter remains unaltered at the close of the operation. It is thus obvious that chlorate of potash, on being decomposed, furnishes considerably more heat than that which is necessary to gasify the oxygen which it evolves. It was therefore necessary to determine the amount of heat thus evolved by the quantity of chlorate of potash ( 9.75 grams) mixed with one gram of the substance burnt in each of the following determinations. This was effected by the use of two copper tubes, the one placed within the other. The interior tube was charged with a known weight of the same mixture of chlorate of potash and peroxyd of manganese as that used for the subsequent experiments, whilst the annular space between the two tubes was flled with a combustible mixture of chlo. rate and spermaceti, the calorific value of which had been previously ascertaiued. The latter mixture was ignited in the calorimeter as before, and the heat generated during its combustion effected the complete decomposition of the chlorate in the interior cylinder, as was proved by a subsequent examination of the liquid in the calorimeter, which contained no traces of undecomposed chlorate. The following are the results of five experiments thus made, expressed in units of heat, the unit being equal to 1 gram of water raised through $1^{\circ} \mathrm{C}$. of temperature:-

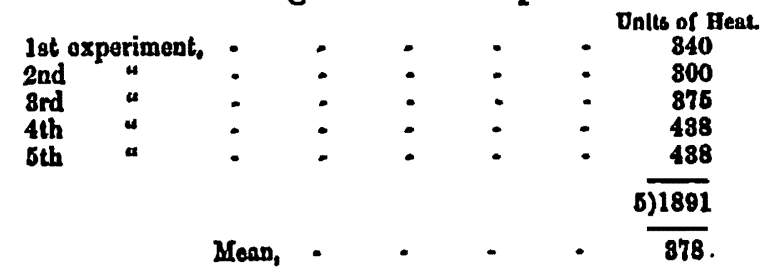


This result was confirmed by the following experiments :-

1. Starch was burnt, firstly, in a current of oxygen gas, and secondly, by admixture with chlorate of potash and peroxyd of manganese.

Elest units fumished by one gram of starch bumt with 975 grams chlorate of potash,

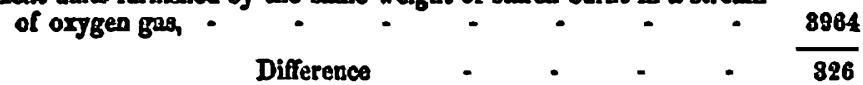

2d. Phenylic alcohol was burnt with chlorate of potash, and the result compared with the calorific value of this substance as determined by Favre and Silbermann.

Heat anits furnished by one gram of phenglic alcohol burat with 0.76 grams chlorate of potash,

Heat units furmished by one gram of phenylic alcohol when burnt with gaseous orygen (Eavre and Silbermann),

\section{Difference, .}

These three determinations of the heat evolved by the decomposition of 9.75 grams of chlorate of potash, furnishing the numbers 378,326 , and 341 , agree as closely as could be expected, when it is considered that all experimental errors are necessarily thrown upon the calorific value of the chlorate of potash.

The mean of the above five experimental numbers was, in all cases, deducted from the actual values read off in the following determinations.

It was ascertained by numerous trials that all the chlorate of potash was decomposed in the deflagrations, and that but mere traces of carbonic oxyd were produced.

Joule's mechanical equivalent of heat was employed, viz., 1 kilogram of water raised $1^{\circ} \mathrm{C} .=423$ meterkilograms.

The following results were obtained:

Actual exergy developed by one gram of cach mbetance when bumt in oxygen.

\begin{tabular}{|c|c|c|c|c|c|c|}
\hline \multirow{2}{*}{$\begin{array}{l}\text { Namo of entreance deled } \\
\text { at } 100^{\circ} \mathrm{C} \text {. }\end{array}$} & \multicolumn{5}{|c|}{ Heat onITs. } & \multirow{2}{*}{$\begin{array}{l}\text { Moter. } \\
\text { Lilograms } \\
\text { of forea. } \\
\text { (Hean.) }\end{array}$} \\
\hline & $\begin{array}{c}\text { Ief Expert. } \\
\text { ment. }\end{array}$ & $\begin{array}{l}20 \text { Expesi- } \\
\text { ment. }\end{array}$ & $\begin{array}{l}\text { 3d Expost- } \\
\text { menlo }\end{array}$ & $\begin{array}{l}\text { 4th Experi- } \\
\text { ment }\end{array}$ & Moan. & \\
\hline $\begin{array}{l}\text { Beef musclo purified } \\
\text { by repeated wash- } \\
\text { ing with ether. }\end{array}$ & 5174 & B089 & 6185 & 5088 & 5108 & 2161 \\
\hline 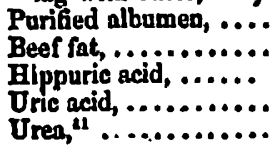 & $\begin{array}{l}5009 \\
9089 \\
6380 \\
2645 \\
2121\end{array}$ & $\begin{array}{l}4987 \\
\ddot{6487} \\
2585 \\
2802\end{array}$ & 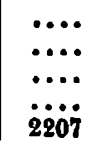 & 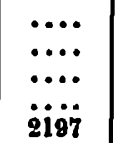 & $\begin{array}{l}4998 \\
9089 \\
6888 \\
2618 \\
2208\end{array}$ & $\begin{array}{r}2117 \\
8841 \\
2280 \\
1108 \\
984\end{array}$ \\
\hline
\end{tabular}

v The speaker showed the combustibility of ures by burning it upon asbestos in a jar of oxygen gas. 
It is evident that the above determination of the actual energy developed by the combustion of muscle in oxygen represents more than the amount of actual energy produced by the oxydation of muscle within the body, because, when muscle burns in oxygen its carbon is converted into carbonic acid, and its hydrogen into water; the nitrogen being, to a great extent, evolved in the elementary state; whereas, when muscle is most completely consumed in the body, the products are carbonic aoid, water and urea; the whole of the nitrogen passes out of the body as urea-a substance which still retains a considerable amount of potential energy. Dry muscle and pure albumen yield, under these circumstances, almost exactly one-third of their weight of urea, and this fact, together with the above determination of the actual energy developed on the combustion of urea, enables us to deduce with certainty the amount of aotual energy developed by muscle and albumen respectively when consumed in the human body. It is as follows:-

Aetral energy developed by one gran of cach substance when consumed in the body.

\begin{tabular}{|c|c|c|}
\hline Neme of substanco dried at $100^{\circ} \mathrm{C}$. & $\begin{array}{c}\text { Ilnat units. } \\
\text { (Mosn.) }\end{array}$ & $\begin{array}{l}\text { Molorillogram } \\
\text { of forea. } \\
\text { (Mean.) }\end{array}$ \\
\hline $\begin{array}{l}\text { Beef muscle purit } \\
\text { Purified albumen. }\end{array}$ & $\begin{array}{l}4868 \\
4983\end{array}$ & $\begin{array}{l}1848 \\
1808\end{array}$ \\
\hline
\end{tabular}

We bave thus ascertained the first of our three data, viz., the amount of force or actual energy generated by the oxydation of a given amount of muscle in the body; and we now proceed to ascertain the second, viz, the amount of mechanical force exerted by the muscles of the body during a given time. For this purpose we have only to avail ourselves of the details of Fick and Wislicenus's conclusive experiment already referred to, and which consisted in the ascent of the Faulhorn in Switzerland from the lake of Brienz. This mountain can be ascended by a very steep path from Iseltwald, which was of.course favorable for the experiment, and there is a hotel on the summit which allowed the experimenters to pass the following night under tolerably normal circumstances. The following is their own description and estimate of the amount of work performed in the ascent."

"Let us now inquire how much work was really done by our muscles. One item necessary for the reply is already at hand, viz., the height of the summit of the Faulhorn above the level of the lake of Brienz multiplied by the weight of the body; the former reckoned in meters, the latter in kilograms. The weight of the body with the equipments (hat, clothes, stick)

"Phil. SIagg, rol. xxxi, p. 496, 1866. 
amounted to 66 kilograms in Fick's case, and 76 in Wislicenus's. The height above the Faulhorn above the level of the lake of Brienz is, according to trigonometric measurements, exactly 1956 meters. Therefore Fick performed 129,096 and Wislicenus 148,656 meterkilograms of muscular work."

But in addition to this measurable external work there is another item of force "which can be expressed in units of work; and though its value cannot be quite accurntely calculated, yet a tolerable approximation can be made. It consists of the force consumed in respiration and the heart's action. The work performed by the heart has been estimated, in a healthy full-grown man, at about 0.64 meterkilogram ${ }^{3}$ for each systole. During the ascent, Fick's pulse was about 120 per minute. That gives for the 5.5 hours of the ascent an amount of work which may be estimated at 25,814 meterkilograms, entirely employed in the maintenance of the circulation. No attempt bas yet been made to estimate the labor of respiration. One of us has shown, however, in the second edition of his 'Medical Physics' (p. 206), that Donders's well-known investigations concerning the conditions of pressure in the cavity of the thorax give sufficient data for such an estimate. He has there shown that the amount of work performed in an inspiration of 600 cubic centims. may be rated at about 0.63 meterkilogram. Fick breathed during the ascent at an average rate of about 25 respirations per minute, which gives, according to this estimation, an amount of respiratory work for the whole ascent of 5197 meterkilograms. If we add this, and the number representing the work of the heart, to the external work performed by Fick, we obtain a total of 159,637 meterkilograms. If we suppose that Wislicenus's respiratory and circulatory work bore the same proportion to Fick's as his bodily weight did to Fick's, i. e., $7: 6$, we obtain for Wislicenus's amount of work, as far as it is possible to calculate it, a total of 184,287 meterkilograms.

"Besides these estimated (and certainly not over-estimated) items, there are several others which cannot be even approximately calculated, but the sum of which, if it could be obtained, would probably exceed even our present large total. We will try to give at least some sort of an account of them. It must first be remembered that in the steepest mountain path there are occasional level portions, or even descents. In traversing such places the muscles of the leg are exerted as they are in ascending, but the whole work performed is transformed back into heat. The same force-producing process, bowever, must be going on in the muscles as if work were being performed which

\footnotetext{
a 0.48 is here asgigned as the work of the left, and 0.21 as that of the right ren.
} tricle. 
did not undergo this transformation. In order to make this point yet clearer we may take into consideration that the whole work of the ascent, only existed temporarily as work. On the following day the result was reversed; our bodies approached the center of the earth by as much as they had receded from it the day before, and, in consequence, on the second day an amount of heat was liberated equal to the amount of work previously performed. The two parts of the action, which in this case were performed on two separate days, take place in walking on level ground in the space of a footstep.

"Let us observe, besides, that in an ascent it is not only those musoles of the leg specially devoted to climbing which are exerted, the arms, head, and trunk are continually in motion. For all these movements force-generating processes are necessary, the result of which cannot, however, figure in our total of work, but must appear entirely in the form of heat, since all the mechanical effects of these movements are immediately undone again. If we raise an arm, we immediately let it drop again, \&a.

"There was besides a large" portion of our muscular system employed during the ascent, which was performing no external work (not even temporary work, or mechanical effects immediately reversed), but which cannot be employed without the same force-generating processes which render external work possible. As long as we hold the body in an upright position, individnal groups of muscles (as, for instance, the muscles of the back, neck, \&c.) must be maintained in a state of continual tetanus in order to prevent the body from collapsing. We may conceive of a tetanized muscle as holding up a weight which would immediately fall if the supply of actual energy were to cease. It is active, but it performs no work, and therefore all the force produced is liberated in the form of heat."

Thus the total amount of measured and estimable work performed in 5.5 hours in the experiments before us was 159,637 meterkilograms for Fick, and 184,287 meterkilograms for Wislicenus. This is our second datum.

The third, viz., the amount of muscle oxydized in the body during the performance of this work has been carefully determined by the same experimenters, as well as the rate of muscle consumption before and after the ascent. For the details of these determinations the spenker referred his hearers to the Philosophical Magazine for 1866, vol. xxxi, p. 488; but the following is a condensed summary of the results:- 
Ascent of the Fatthorn.

\begin{tabular}{|c|c|c|}
\hline & Flok & Whalleones \\
\hline $\begin{array}{l}\text { Amount of nitrogen secreted in uripe per hour before ascent, } \\
\text { Weight of dry nuscle corresponding to nitrogen, ........... }\end{array}$ & $\begin{array}{r}63 \\
4.10 \\
\end{array}$ & $\begin{array}{r}61 \\
4.08 \\
\end{array}$ \\
\hline $\begin{array}{l}\text { Amount of nitrogen secreted per hour during ascent,.......... } \\
\text { Weightit of dry muscle corresponding to nitroget, } \ldots \ldots \ldots \ldots \ldots\end{array}$ & $\begin{array}{r}41 \\
2 \cdot 70\end{array}$ & $\begin{array}{r}\cdot 89 \\
2.86\end{array}$ \\
\hline 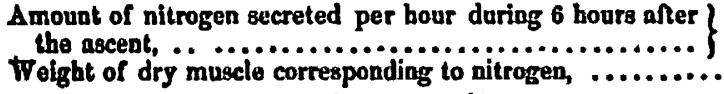 & $\begin{array}{r}40 \\
2 \cdot 68 \\
\end{array}$ & $\begin{array}{r}\cdot 40 \\
2 \cdot 68 \\
\end{array}$ \\
\hline 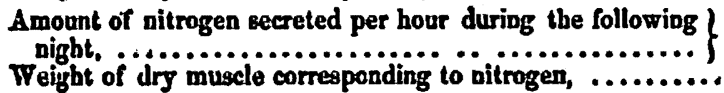 & 96 & $\begin{array}{r}61 \\
8.89\end{array}$ \\
\hline \multirow[t]{2}{*}{$\begin{array}{l}\text { Total amount of nitrogen secreted during ascent, } \ldots \ldots \ldots \ldots \ldots \\
\text { Ditto during } 6 \text { hours after ascent, } \ldots \ldots \ldots \ldots \ldots \ldots \ldots \ldots \ldots\end{array}$} & $\begin{array}{l}3.31 \\
2.48\end{array}$ & $\begin{array}{l}8 \cdot 18 \\
2 \cdot 42\end{array}$ \\
\hline & 5.74 & 6.85 \\
\hline \multirow[t]{2}{*}{$\begin{array}{l}\text { Weight of dry muscle correspond- } \\
\text { ing to nitrogen secreted, }\end{array}\left\{\begin{array}{l}\text { During akcent, } \ldots \ldots \ldots . . . . \\
\text { During } 6 \text { hours after aecent, }\end{array}\right.$} & $\begin{array}{l}2098 \\
16 \cdot 19\end{array}$ & $\begin{array}{l}20 \cdot 89 \\
16 \cdot 11\end{array}$ \\
\hline & $87 \cdot 17$ & 87.00 \\
\hline
\end{tabular}

The results of these determinations add a new link to the chain of experimental evidence, that muscular exertion does not. necessatily increase the excretion of nitrogen through the urine, From mid.day before the ascent (August 29th, 1865) to the following evening at seven o'clock (A ugust 30th) both gentlemen: abstained from all nitrogenous food. During these thirty-one hours they bad nothing in the way of solid food except starch, fat, and sugar. The two former were taken in the form of cakes. Starch was made up with water into a thin paste, which was then made into small cakes and fried with plenty of fat. The sugar was taken dissolved in tea. In addition to this there wass the sugar contained in the beer and wine, which were taken in quantities usual in mountain excursions. It was doubtless owing to this absence from food containing nitrogen that the amount of this element secreted through the urine, declined tolerably regularly from the 29th of August till the evening of the 30th. Even in the night of the 30th to the 31st, in spite of the plentiful menl of albuminous food on the evening of the 30th, the secretion of nitrogen was less than on the preceding night. The renson of this is probably to be sought for in the circumstance that during the period of abstinence, the secretion of nitrogen was carried on at the expense of tissues, and now these tissues required reparation.

It is perhaps scarcely worthy of record that during the ascent neither of the experimenters perspired perceptibly, since it has been proved by Ranke that no appreciable amount of nitrogen leaves the system in the matter of perspiration; and as Thiry has also shown that no nitrogen is got rid of by respiration, it follows that in addition to the nitrogen contained in the urine,

Ax. Jour. Bct.-BgcoNd SERTrs, Vor. XLII, No. 128.-Nov., 1866. 
the only other mode of exit for this element is through the freces. Now the proportion secreted through the freces has been estimated by Ranke at about one-twelfth of that in the urine; but inasmuch as all experiments on the subject tend to show that this alvine nitrogen is, as voided, a constiluent of un-oxydized compounds, that is, of compounds that have not yielded up their force, it has no claim upon our attention.

There is still another circumstance which requires to be taken into consideration before we proceed to apply our three data to the solution of the problem before us. It is this:-Is it possible that at the termination of the ascent of the Faulhorn there might be a considerable quantity of the nitrogenous products of decomposition retained in the body? Considering the physiological effect of the retention of urea in the system, as exemplified whenever the secretion of urine is interrupted, it is difficult to imagine the possibility of any considerable quantity of urea being retained in the system of a healthy man. It is, however, otherwise with creatin, another of the products of the metamorphosis of tissue; for it has been repeatedly shown that a muscle which has been hard worked contains more creatin than one that has been at rest. 'Thus the quantity of creatin contained in the heart of an ox was found to be 14 per cent (Gregory), and that in other ox-flesh only 06 per cent (Staedeler). Now the muscles which extend the leg in walking, and which do the essential work in ascending, have been estimated by Weber to weigh in both legs 5.8 kilograms, and if we assume that before the ascent these muscles contained 06 per cent of creatin, while after the ascent the percentage had increased to $\cdot 14$ per cent, then the amount of creatin thus exceptionally retained would amount to 4.64 grams, which would be derived from 8.4 grams of muscle.

The speaker had been unable to determine the calorific effect of creatin, and consequently the actual energy developed by the transformation of muscle into creatin; for, although he was kindly furnished with an ample supply of this material by Dr. Dittmar, yet all attempts to burn it in the calorimeter were fruitless. Even when mixed in very small proportions with chlorate of potash and other combustibles of known value, the mixture invariably exploded violently on ignition. Although actual determination thus fails us, there can be no doubt that the transformation of muscle into creatin and other non-nitrogenous products must be attended by the liberation of far less actual energy than its transformation into urea, carbonic acid, and water. To be convinced of this, it is only necessary to compare (under equal nitrogen value) the formulæ of muscle, creatin, and urea, remembering at the same time that the nitrogen probably pos. sesses no thermal value, and that each atom of oxygen destroys approximately the thermal effect of two atoms of hydrogen. 


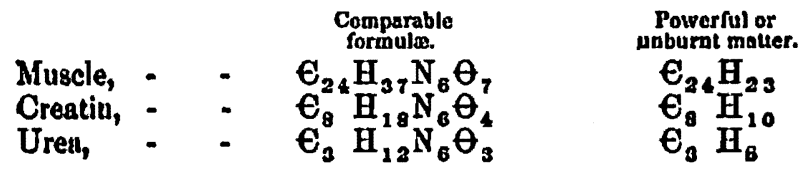

Thus it is evident that the amount of creatin exceptionally retained in the system could not greatly affect the result of the experiment as regards the possible amount of actual energy derivable from the metamorphosed tissues during the ascent; firstly, on account of the small quantity of creatin so retained, and, secondly, because creatin still contains about one-third of the potential energy of the muscle from which it is derived. But as this point cannot be experimentally demonstrated, the spenker followed the example of Fick and Wislicenus, and made a very liberal allowance on this score. He allowed, as they had done, that the whole of the nitrogen secreted during the six hours after the ascent was exceptionally retained in the system as urea during the ascent. This is equivalent to an admission that the muscles of the legs contained at the end of the ascent eleven times as much creatin as was present in them before the ascent. In the above tabular statement of results provision bas been made for this allowance by adding together, on the one hand, the amounts of nitrogen secreted during the ascent and six hours after it, and, on the other, the weights of dry muscle corresponding to these two amounts of nitrogen.

Having thus far cleared the ground, let us now compare the amount of measured and calculated work performed by each of the experimenters during the ascent of the Faulhorn, with the actual energy capable of being developed by the maximum amount of muscle that could have been consumed in their bodies, this amount being represented by the total quantity of nitrogen excreted in each case during the ascent and for six hours afterwards.

\begin{tabular}{|c|c|c|}
\hline & Pick: & Wisliconge \\
\hline Weight of dry muscle consumed,............. & $\begin{array}{l}\text { Grama. } \\
87 \cdot 17\end{array}$ & $\begin{array}{l}\text { Grams. } \\
87.00\end{array}$ \\
\hline 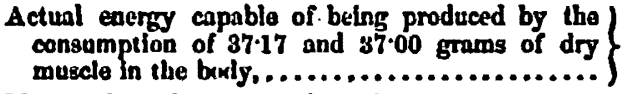 & $\begin{array}{c}\text { Motorkilagrnms. } \\
68,690\end{array}$ & $\begin{array}{c}\text { Motorkilograme } \\
68,878\end{array}$ \\
\hline 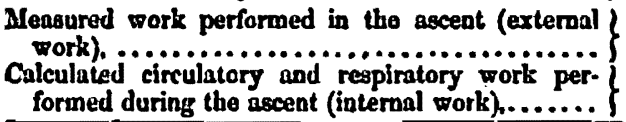 & $\begin{array}{r}129,096 \\
80,541\end{array}$ & $\begin{array}{r}148,666 \\
86,681\end{array}$ \\
\hline Total ascertainable work perfnrmed,........... & 168,687 & $184,28 \overline{7}$ \\
\hline
\end{tabular}

It is thus evident that the muscular power expended by these gentlemen in the ascent of the Faulhorn could not be exclusively derived from the oxydation, either of their inuscles, or of other nitrogenous constituents of their bodies, since the maximum of 
power capable of being derived from this source even under very favorable assumptions is, in both cases, less than one-half of the work actually performed. But the deficiency becomes much greater if we take into consideration the fact, that the actual energy developed by oxydation or combustion cannot be wholly transformed into mechanical work. In the best constructed steam-engine, for instance, only one-tenth of the actual energy developed by the burning fuel can be obtained in the form of mechanical power; and in the case of man, Helmholtz estimates that not more than one-fifth of the actual energy deyeloped in the body can be made to appear as external work. The experiments of Haidenhain, however, show that, under favorable circumstances, a muscle may be made to yield, in the shape of mechanical work, as much as one-half of the actual energy developed within it, the remainder taking the form of heat. Taking then this highest estimate of the proportion of mechanical work capable of being got out of actual energy, it becomes necessary to multiply by two the above numbers representing the ascertainable work performed, in order to express the actual energy involved in the production of that work. We then get the following comparison of the actual energy capable of being developed by the amount of muscle consumed, with the actual energy necessary for the performance of the work executed in the ascent of the Faulhorn.

\begin{tabular}{|c|c|c|}
\hline & Fick. & Wraticenus. \\
\hline & Motarkilograms. & Petorkilograms. \\
\hline $\begin{array}{l}\text { Actual exergy capable of being produced by } \\
\text { muscle metamorphingis, ................ }\end{array}$ & 68,690 & 68,376 \\
\hline Actual energy expended in work performed,... & 819,274 & 868,674 \\
\hline
\end{tabular}

Thus, taking the average of the two experiments, it is evident that scarcely one-fifth of the actual energy required for the work performed could be oblained from the amount of muscle consumed.

Interpreted in the sume way, previous experiments of a like kind prove the same thing, though not quite so conclusively, To illustrate this I will here give a summary of three sets of experiments: the first, made by Dr. W. Smith, upon prisoners engaged in treadmill labor; the second, by the Rev. Dr. Haughton, upon military prisoners engaged in shot drill; and the third, adduced by Playfair and made upon pedestrianB, pile-drivers, men turning a winch, and other laborers.

Treadwheel experiments, $-\mathrm{A}$ tread wheel is a revolving drum with steps placed at distances of eight inches, and the prisoners are required to turn the wheel downwards by stepping upwards. Four prisoners, designated below as A, B, C, and D, were em. ployed in these experiments, and each worked upon the whecl in alternate quarters of an hour, resting in a sitting posture dur. ing the intervening quarters. The period of actual daily labor 
was $3 \frac{1}{2}$ bours. The total ascent per hour 2160 feet, or per day 1.432 mile. The following are the results:-

Treadeoheel work-(E. Smith.)

\begin{tabular}{|c|c|c|c|c|c|c|}
\hline & $\begin{array}{l}\text { Woigbe in } \\
\text { tillogramn. }\end{array}$ & $\begin{array}{l}\text { Aecent ia } \\
\text { motere. }\end{array}$ & $\begin{array}{l}\text { Doye } \\
\text { occupiod } \\
\text { to secont. }\end{array}$ & $\begin{array}{c}\text { External werk } \\
\text { performed in } \\
\text { mecorkilograma. }\end{array}$ & $\begin{array}{c}\text { Total } \\
\text { plerogep } \\
\text { ovolved. }\end{array}$ & $\begin{array}{l}\text { Woight of dry } \\
\text { muenle corres. } \\
\text { ponding to } \\
\text { nltrogun. }\end{array}$ \\
\hline $\begin{array}{l}\mathbf{A} \\
\mathbf{B} \\
\mathbf{O} \\
\mathbf{D}\end{array}$ & $\begin{array}{l}47 \cdot 6 \\
49 \\
65 \\
66\end{array}$ & $\begin{array}{l}28,045 \\
23,045 \\
20,741 \\
20,741\end{array}$ & $\begin{array}{r}10 \\
10 \\
8 \\
9\end{array}$ & $\begin{array}{l}1,096,942 \\
1,129,206 \\
1,140,766 \\
1,161,496\end{array}$ & $\begin{array}{l}\text { Grams. } \\
171 \cdot 3 \\
174 \cdot 5 \\
168 \cdot 0 \\
159 \cdot 3\end{array}$ & $\begin{array}{l}\text { Grame } \\
1101 \cdot 2 \\
11: 1 \cdot 7 \\
1080: 1 \\
1024 \cdot 3\end{array}$ \\
\hline
\end{tabular}

In these experiments the measured work was performed in the short space of $3 \frac{1}{2}$ hours, while the nitrogen estimated was that voided in the shape of urea in 24 hours. It will, therefore, be necessary to add to the measured work that calculated for respiration and circulation for the whole period of 24 hours. This amount of internal work was computed, from the estimates of Helmholtz and Fick, to be as follows:-

\begin{tabular}{|c|c|c|}
\hline \multicolumn{3}{|c|}{ Internal work. $\sim$ (Helmholtz and Fick.) } \\
\hline & $\begin{array}{c}\text { Work } \\
\text { porformed. }\end{array}$ & $\begin{array}{l}\text { Aetual onergy } \\
\text { required. }\end{array}$ \\
\hline \multirow{5}{*}{ 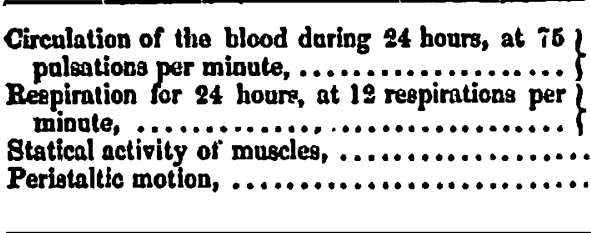 } & SLetorkilograms. & IIotarkillograma \\
\hline & $69,120^{10}$ & 138,240 \\
\hline & 10,886 & 21,772 \\
\hline & ${ }_{\|}^{\text {not determined. }}$ & not determined. \\
\hline & $80,0 \overline{6}$ & 160.012 \\
\hline
\end{tabular}

Taking this estimate for internal work, the average results of the treadwheel experiments may be thus expressed:-

\section{Treadsoleel esork.}

Aremge external work per man per day,

Avernge nitrogen evolved per man per day, -

per day, - -

Actual energy producible by the consumption of 114 grams of dry

muscle in the body, -
Avernge actual energy developed in the body of ench man, viz-
External work.

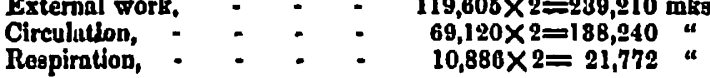

119,606 mkg. $17 \cdot 7$ grams.

$114 "$

210,672 mks.

In these experiments the conditions were obviously very unfavorable for the comparison of the amount of actual energy producible from muscle metamorphosis, with the quantity of actual energy expended in the performance of estimable work;

11 Since making use of this number, I find that Donders estinates the work of the heart alone, for 24 hours, at 86,000 meterkilograms, a figure which is highor than that above for the combined work of circulntion and respiration. 
since, during that portion of the twenty-four hours not occupied in the actual experiment, a large amount of unestimable internal work, such as the statical activity of the musoles, peristaltic motion, \&c., was being performed. Nevertheless, these experiments show that the average actual energy developed in producing work in the body of each man was nearly twice as great as that which could possibly be produced by the whole of the nitrogen. ous matter oxydized in the body during 24 hours. It must also be remarked that the prisoners were fed upon a nitrogenous diet containing six ounces of cooked meat, without bone; a diet which, as is well known, would favor the production of urea.

Shot-drill experiments. - The men employed for these experiments were fed exclusively upon vegetable diet, and they consequently secreted a considerably smaller amount of nitrogen than the flesh-eaters engaged in the treadwheel work. 'The other conditions were, however, equally unfavorable for showing the excess of work performed, over the amount derivable from muscle metamorphosis.

In shot-drill, each man lifts a $32 \mathrm{lb}$. shot from a tressel to his brenst, a height of 3 feet; he then carries it a distance of 9 feet, and lays it down on a similar support, returning unloaded. Six of these double journeys occupy one minute. The men were daily engaged with-shot-drill 3 hours, ordinary drill $1 \frac{1}{4}$ hours, oakum picking $3 \frac{1}{2}$ hours.

The total average daily ezternal work was estimated by Haughton at 96,316 meterkilograms per man.

The following is a condensed summary of the results of these experiments:-

Military vegetarian prisoners at shot-drill.-(Haughton.)

Avernge external work per man per day, _ - _ _ _ - 96,816 mks,

Avernge nitrogen ovolyed per man per day, - _ - - 12.1 grams.

Weight of dry muscle corresponding to average nitrogen evolvad per day,

Actual energy producible by the consumption of 77.9 grams of

dry muscle in the body,

Average actual energy developed daily in the

body of each man, viz, External work,

$98,816 \times 2=$ - - * - $192,632 \mathrm{mkg}$.

Internal work, - - - - 160,012 a

852,644 mks.

Owing chiefly to the vegetable diet of these prisoners, the result is more conclusive than that obtained upon the treadwheel, the amount of work actually performed being considerably more than twice as great as that which could possibly be obtained through the muscle metamorphosis occurring in the bodies of the prisoners.

Playfair's determinations.-In these determinations the number 109,496 meterkilograms was obtained as the average amount 
of daily work performed by pedestrians, pileddrivers, porters, paviors, \&c.; but, as the amount of muscle consumption is cal. culated from the nitrogen taken in the food, the conditions are as unfavorable as possible with regard to the point the speaker was seeking to establish; for it is here assumed, not only that all the nitrogen taken in the food enters the blood, but also that it is converted into muscle, and is afterwards oxydized to carbonic acid, water, and urea. The following are the results expressed as in the previous cases:-

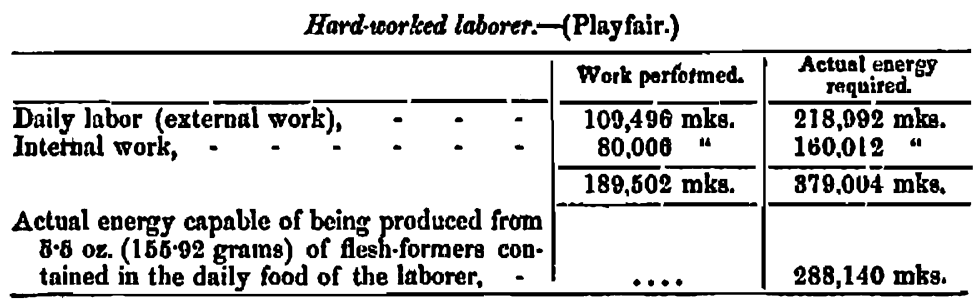

Thus, even under the extremely unfavorable conditions of these determinations, the actual work performed exceeded that which could possibly be produced through the oxydation of the nitrogenous constituents of the daily food by more than 30 per cent.

We have seen, therefore, in the above four sets of experiments, interpreted by the data afforded by the combustion of mascle and urea in oxygen, that the transformation of tissue alone cannot account for more than a small fraction of the muscular power developed by animals $;$ in fact, this transformation goes on at a rate almost entirely independent of the amount of muscular power developed. If the mechanical work of an animal be doubled or trebled there is no corresponding increase of nitrogen in the secretions ; whilst it was proved on the other hand by Lawes and Gilbert, as early as the year 1854, that animals, under the same conditions as regarded exercise, had the amount of nitrogen in their secretions increased twofold by merely doubling the amount of nitrogen in their food. Whence then comes the muscular power of animals? What are the substances which, by their oxydation in the body, furnish the actual energy, whereof a part is converted into muscular work? In the light of the experimental results detailed above, can it be doubted that a large proportion of the muscular power developed in the bodies of animals has its origin in the oxydation of non-nitrogenous substances? For while the secretion of nitrogen remains nearly stationary under widely different degrees of muscular exertion, the production of carbonic acid increases most markedly with every augmentation of muscular work. as is shown by the following tabulated results of E. Smith's highly important experi- 
ments regarding the amount of carbonic acid evolved from his own lungs under different circumstances. ${ }^{10}$

Excretion of carbonic acid during rest and muscular exertion :-

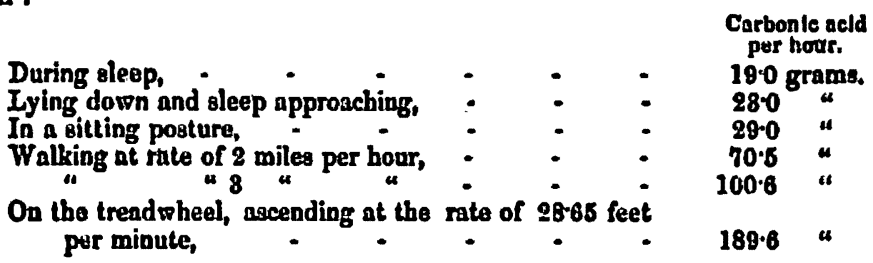

It has been already stated as a proposition upon which all are agreed, that food, and food alone, is the ultimate source from which muscular power is derived; but the above determinations and considerations, the speaker believed, prove conclusively, firstly, that the non-nitrogenous constituents of the food, such as starch, fat \&c., are the chief sources of the actual energy, which becomes partially transformed into muscular work; and secondly, that the food does not require to become organized tissue before its metamorphosis can be rendered available for muscular power; its digestion and assimilation into the circulating fluid - the blood -being all that is necessary for this purpose. It is, however, by no means the non-nitrogenous portions of food alone that are capable of being so employed, the nitrogenous also, inasmuch as they are combustible, and consequently capable of furnishing actual energy, might be expected to be available for the same pur. pose, and such an expectation is confirmed by the experiments of Savory upon rats, ${ }^{16}$ in which it is proved that these animals can live for weeks in good henlth upon food consisting almost exclusively of muscular fibre. Even supposing these rats to bave performed no external work, nearly the whole of their internal musculur work must have had its source in the actual energy developed by the oxydation of their strictly nitrogenous food.

It can scarcely be doutted, however, that the chief use of the nitrogenous constituents of food is for the renewal of muscular tissue; the latter, like every other part of the body, requiring a continuous change of substance, while the chief function of the non-nitrogenous is to furnish by their oxydation the actual en. ergy which is in part transmuted into muscular force.

The combustible food and oxygen coëxist in the blood which courses through the muscle, but when the muscle is at rest there is no chemical action between them. A command is sent from the brain to the muscle, the nervous agent determines oxydation. The potential energy becomes active energy, one portion assum. ing the form of motion, another appearing as heat. Here is the

\footnotetext{
"s Phil. Truns. for 1850, p. $709 . \quad$ to The Laveet, 1868, pages 881 and 112.
} 
source of animal heat, here the origin of muscular power / Like the piston and cylinder of a steam.engine, the muscle itself is only a machine for the transformation of beat into motion; both aro subject to wear and tear and require renewal, but neither contributes in any important degree by its own oxydation to the actual production of the mechanical power which it exerts.

From this point of view it is interesting to examine the various articles of food in common use, as to their capabilities for the production of muscular power. The speaker had therefore made careful estimations of the calorific value of different materials used as food, by the same apparatus and in the same manner as described abovo for the determination of the actual energy in muscle, urea, uric acid, and hippuric acid.

The results are embodied in the following series of tables, but it must be borne in mind that it is only on the condition that the food is digested and passes into the blood, that the results given in these tables are realized. If, for instance, sawdust or paraffin oil had been experimented upon, numbers would have been obtained for these substances, the one about equal to that assigned to starch, and the olber surpassing that of any article in the table; but theso numbers would obviously bave been ntterly fallacious, inasmuch as neither sawdust nor paraffin oil is, to any appreciable extent, digested in the alimentary canal. While the force-values experimentally obtained for the different articles in these tables must therefore be understood as tho maxima assignable to the substances to which they belong, yet it must not be forgotten that a large majority of these substances appear to be completely digestible under normal circumstances.

Actual energy developed by one gram of rarious articles of food when burnt in axygen.

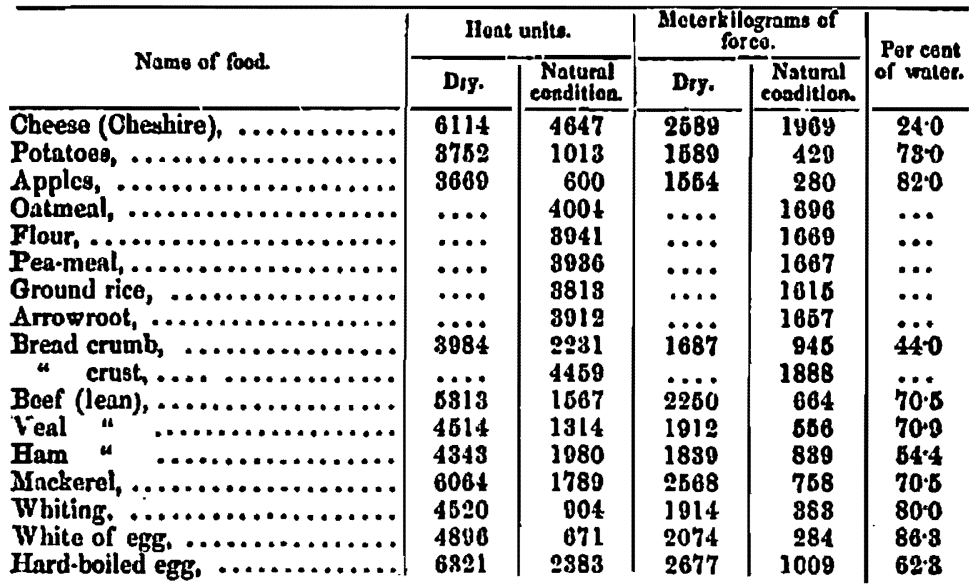

Axc Jour. 8cr.-8Eaond SERIE, Voz. XLII, No. 126-Nov., 1866 
Actual energy developed by one gram of various articles of food-continued.

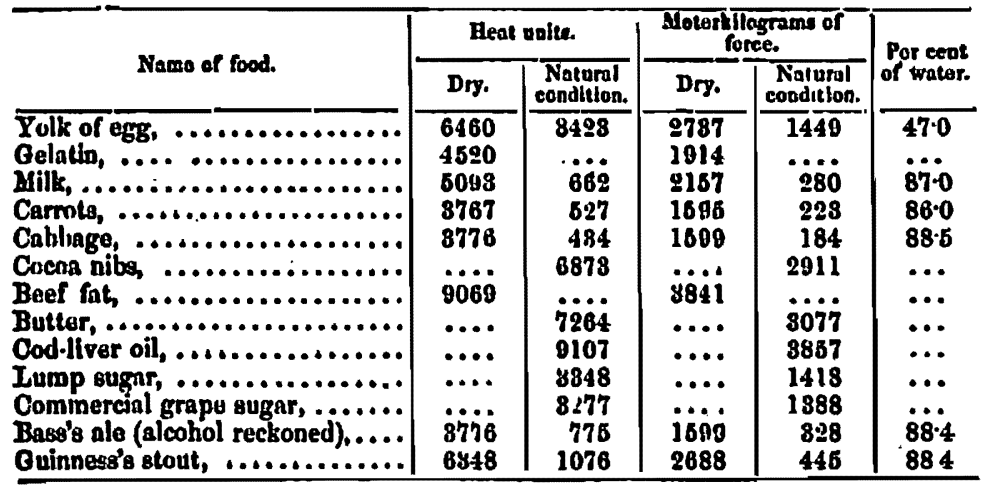

Aetual exergy developed by one gram of various articles of food when axydized in the body.

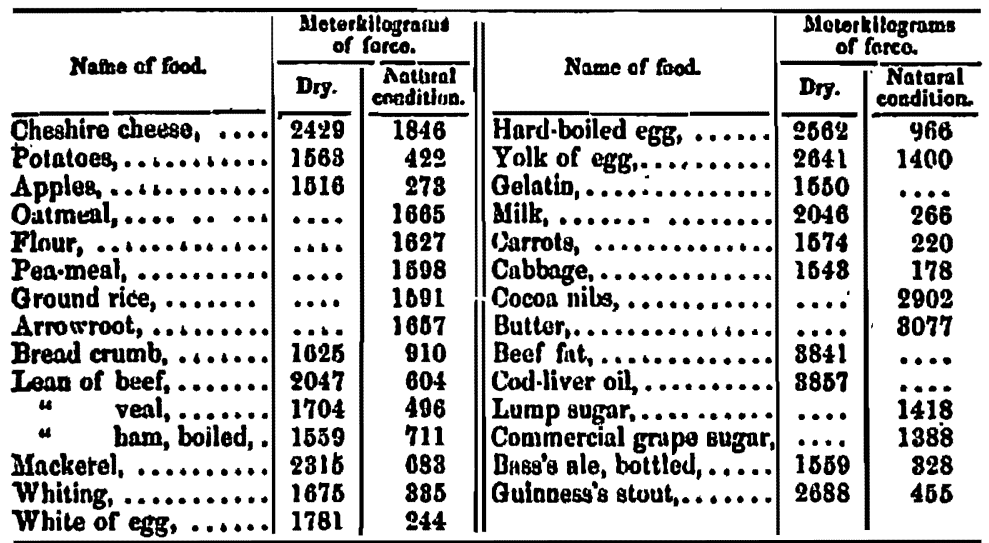

Weight and cost of various articles of food reguired to be axydized in the body in order to raise 14068 . to the height of 10,000 feet.

External work $=\frac{1}{3}$ th actual energy.

\begin{tabular}{|c|c|c|c|}
\hline Name of food. & $\begin{array}{l}\text { Woight } \\
\text { In lbes. } \\
\text { roquired. }\end{array}$ & Prico por th. & Cost. \\
\hline 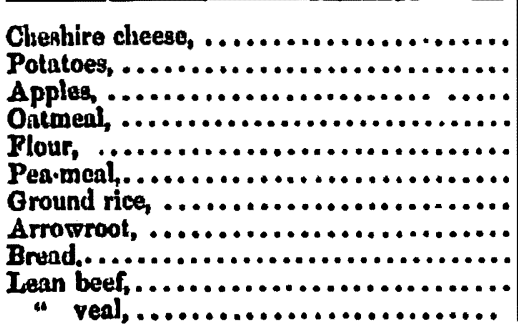 & $\begin{array}{l}1 \cdot 166 \\
8 \cdot 068 \\
7 \cdot 816 \\
1 \cdot 981 \\
1 \cdot 311 \\
1 \cdot 835 \\
1 \cdot 841 \\
1 \cdot 987 \\
2 \cdot 846 \\
8 \cdot 532 \\
4 \cdot 800\end{array}$ & $\begin{array}{cc}8 . & d . \\
0 & 10 \\
0 & 1 \\
0 & 1 \\
0 & 24 \\
0 & 24 \\
0 & 3 t \\
0 & 4 \\
1 & 0 \\
0 & 2 \\
1 & 0 \\
1 & 0\end{array}$ & 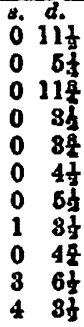 \\
\hline
\end{tabular}


Weight and cost of various articles of food-continued.

\begin{tabular}{|c|c|c|c|}
\hline Name of food. & $\begin{array}{l}\text { Weight } \\
\text { in Ibs. } \\
\text { required. }\end{array}$ & Prico per th. & Cost. \\
\hline 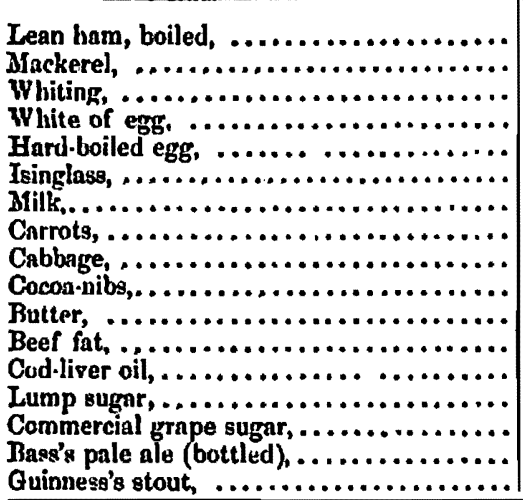 & 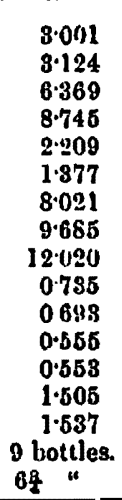 & $\begin{array}{|cc|} & d \\
1 & 6 \\
0 & 8 \\
1 & 4 \\
0 & 6 \\
0 & 6 \frac{1}{2} \\
16 & 0 \\
5 d . & \text { per } \\
0 & \text { quart. } \\
0 & 1 \\
1 & 6 \\
1 & 6 \\
0 & 10 \\
3 & 6 \\
0 & 6 \\
0 & 8 \frac{1}{2} \\
0 & 10 \\
0 & 10\end{array}$ & $\begin{array}{cc}8 . & d . \\
4 & 6 \\
2 & 1 \\
9 & 4 \\
4 & 4 \frac{1}{2} \\
1 & 2 \frac{1}{4} \\
22 & 0 \frac{1}{2} \\
1 & 8 \frac{1}{4} \\
1 & 2 \frac{1}{2} \\
1 & 04 \frac{1}{4} \\
1 & 1 \frac{1}{4} \\
1 & 0 \frac{1}{2} \\
0 & 5 \frac{1}{4} \\
1 & 11 \frac{1}{4} \\
1 & 8 \\
0 & 6 \frac{1}{2} \\
7 & 6 \\
5 & 7 \frac{1}{4}\end{array}$ \\
\hline
\end{tabular}

Weight of tarious articles of food required to sustain respiration and circulation in the body of an average man during 24 hours.

\begin{tabular}{|c|c|c|c|}
\hline Nome of food. & Weight in oz & Name of food. & Weigbt $\ln \alpha$. \\
\hline Clseshire cheese, . . . . . . . & 8.0 & Whiting.......... & $16 \cdot 8$ \\
\hline Potatoes,.............. & $18 \cdot 4$ & White of egg,.......... & $28 \cdot 1$ \\
\hline Apples,.... & 20.7 & Hard-boiled egg, . . . . . . & $5 \cdot 8$ \\
\hline Oatmeal, & $3 \cdot 4$ & Gelatine, ............... & $8 \cdot 6$ \\
\hline Flour, ... & 3.5 & Mtilk, ..............., & $21 \cdot 2$ \\
\hline Pen-meal, & 8.6 & Carrots, ............ & $25 \cdot 6$ \\
\hline Ground rice, & 3.6 & Cabbage,........... & $81 \cdot 8$ \\
\hline Arrowroot, & $3 \cdot 4$ & Cocoa-nibs, ........ & $i \cdot 9$ \\
\hline Bread, ..... & 64 & Butter,........... & $1 \cdot 8$ \\
\hline Lean beef,. & $9 \cdot 3$ & Cod-liver oil.......... & $1 \cdot 5$ \\
\hline " veal, $\ldots \ldots \ldots \ldots \ldots$ & $11 \cdot 4$ & Lump sugar, . . .......... & $8 \cdot 9$ \\
\hline " ham, boiled,.... & $7 \cdot 9$ & Commercial grape sugar,... & $\mathbf{4} 0$ \\
\hline Mlackerel, . . . . . . . . & $8 \cdot \mathbf{8}$ & & \\
\hline
\end{tabular}

These results are in many instances fully borne out by expe. rience. The food of the agriculturnl laborers in Lancashire contains a large proportion of fat. Besides the very fat bacon which constitutes their animal food proper, they consune large quantities of so-called apple dumplings, the chief portion of which consists of paste in which dripping and suet are large ingredi, ents, in fact these dumplings frequently contain no fruit at all. Egg and bacon pies and potuto pies are also very common pieces de résistance during harvest-time, and whenever very hard work is required from the men. The speaker well remembers being profoundly impressed with the dinners of the navigators employed in the construction of the Lancaster and Preston Railway; they consisted of thick slices of bread surmounted with massive blocks of bacon, in which mere streaks of lean were vis. ible. Dr. Piccard states that the Chamois hunters of Western Switzerland are accustomed, when starting on long and fatiguing 
expeditions, to take with them, as provisions, nothing but baconfat and sugar, because, as they say, these substances are more nourishing than meat. They doubtless find that in fat and sugar they can most conveniently carry with them a store of force-producing matter. The above tables affirm the same thing. They show that $55 \mathrm{lb}$. of fat will perform the work of $1.15 \mathrm{lb}$. cheese, $5 \mathrm{lbs}$. potatoes, $1.3 \mathrm{lb}$. of flour or pea-meal or of $3 \frac{1}{2} \mathrm{lbs}$. of lean beef. Donders, in his admirable pamphlet ' $O n$ the Constituents of Food and their Relation to Muscular Work and Animal Heat,' mentions the observations of Dr. M. C. Verloren on the food of insects. The latter remarks, "Many insects use during a period in which very little muscular work is performed food containing chiefly albuminous matter; on the contrary, at a time when the muscular work is very considerable, they live exclusively, or almost exclusively, on food free from nitrogen." He also mentions bees and butterflies as instances of insects performing enormous muscular work, and subsisting upon a diet containing but the merest traces of nitrogen.

We thus arrive at the following conclusions:-

1. The muscle is a machine for the conversion of potential energy into mechanical force.

2. The mechanical force of the muscles is derived chiefly, if not entirely, from the oxydation of matters contained in the blood, and not from the oxydation of the muscles themselves.

3. In man the chief materials used for the production of muscular power are non-nitrogenous; but nitrogenous matters can also be employed for the same purpose, and hence the greatly increased evolution of nitrogen under the infuence of a flesh diet, even with no greater muscular exertion.

4. Like every other part of the body, the muscles are constantly being renewed; but this renewal is not perceptibly more rapid during great muscular activity than during comparative quiescence.

5. After the supply of sufficient albuminized matters in the food of man to provide for the necessary renewal of the tissues, the best materials for the production, both of internal and external work, are non-nitrogenous matters, such as oil, fat, sugar, starch, gum, \&c.

6. The non-nitrogenous matters of food, which find their way into the blood, yield up all their potential energy as actual en. ergy; the nitrogenous matters, on the other hand, leave the body with a portion (one-seventh) of their potential energy unexpended.

7. The transformation of potential energy into muscular power is necessarily accompanied by the production of heat within the body, even when the muscular power is exerted externally. This is doubtless the chief and, probably, the only source of animal heat. 